\title{
The SWOT Analysis to the Development of Golf Tourism in Yunnan Province
}

\author{
Guo Zhifeng ${ }^{1}$ \\ Department of physical education in Kunming university \\ of science and technology \\ Kunming,China \\ 471563075@qq.com
}

\author{
Zhang Lin $^{2}$ \\ Yunnan open university \\ Kunming,China \\ 751271738@qq.com
}

\begin{abstract}
Golf tourism is a business tourism and leisure project which combines the golf event and tourism. SWOT method is a common method for system analysis. Based on SWOT method, yunnan golf tourism market is analysed and its advantages and disadvantages are found out, which will do good to the golf tourism market in yunnan on exerting advantages, converting disadvantages, grasping opportunities as well as meeting challenges. This paper puts forward the strategies and opinions of the development of golf tourism in yunnan province based on the evaluation of golf tourism in yunnan province in order to promote the development of yunnan tourism in high-end brands.
\end{abstract}

\section{Keywords - Golf tourism; yunnan; SWAT analysis}

\section{THE SWOT ANALYSIS OF THE DEVELOPMENT OF GOLF TOURISM IN YUNNAN PROVINCE}

The development of golf in Yunnan relatively lags behind many regions across the country, but its development is so rapid and it enjoys the reputations both at home and abroad..In 1997, the first golf course in yunnan called "the rural golf business club" was built. And now it sets up 14 courses which situated in five cities: kunming, lijiang, xishuangbanna, Dali and tengchong. In addition, the numbers of courses under construction and in plans have reached for as many as 30. Compared with world famous golf courses, China has four golf courses in the world top 10, 2 of which belongs to yunnan. If we analyze the golf courses in yunnan we will find that they are of good quantities and services in China. According to the incomplete statistics, in 1998-2006 there are seven clubs and eight 18holes courses in yunnan, and the whole golf courses received over 603,000 players, including domestic tourists 298,000 person-time and outside tourists 305,000 person-time. In the first half of 2006 the entire golf industry created 6.07 billion yuan, in which the investment capital is 1.83 billion yuan and the pay tax is 126 million yuan.

\section{A. Advantages analysis}

\section{I)climate advantages}

"You can play 365 days a year in yunnan province". This is a common slogan in yunnan golf circle. Yunnan's pleasant climate makes people feel very comfortable when playing. Grasses is essential in Golf course, the natural superior environment formed by its climates makes the forest coverage rate 52.9\%. This "oxygen bar" helps the lawn to keep good conditions and develops the courses of high quality.

\section{II)terrain advantages}

Commonly the terrain of golf courses is complicated and not flat, the terrain in yunnan is in accordance with that. Mountains accounts for $94.5 \%$ the total areas, and most of which is not suitable for farming, part of the soils can grow corn, but its utilization rate is low. If these areas can be used for golf courses, not only avoiding the conflict between the course construction and farmland protection but also increasing the intensity of green vegetation.

\section{III)tourism resources advantage}

Under the atmosphere of"second venture in tourism" yunnan province introduces 40 key tourist cities and counties, 60 tourist towns, 200 tourist villages of great characteristics, 10 national parks and 50 leisure vacation destinations. Six big tourist areas are ventured and developed meanwhile, that's the advantages compared with other provinces.

IV)policy advantage

In 2005, yunnan tourism carried the banner of"second pioneering", and focused on the transformation of tourism development modes. It aimed for the compound tourism which combined with sightseeing, leisure and vocation. Government supported reasonable golf projects and some tax reduction policies had been made. Now the golf course tax has been dropped from $23 \%$ to $10 \%$, which promotes the golf tourism industry to a great extent. As the first tourist reform province, yunnan tourism is gradually transforming to the stage of leisure tourism. Recently yunnan bridgehead construction plans are approved, as the plateau sports training base yunnan will greatly boost the confidence and will obtain the most favorable supporting policies.

\section{B. Weakness analysis}

\section{I)cognition bias}

In China now golf event hasn't formed certain industry of large scale, and the periods of its development is not long. In light of its high fees and consumptions, it is expensive for most of us, not to mention golf tourism. But in fact is that the expenses one golf tourists costs amounts to the expense that 3 or 4 ordinary tourists costs. Meantime golf takes nature scene as its topics, that's the very living scene that people pursuits. Beyond that golf tourism can increase the job chances and promote the development of local economic, it even can have some chain effects to others related industries.

II)government lags behind and professional talents 


\section{insufficient}

Due to the weak consciousness of golf tourism, the most big obstacle placed in the way is the insufficient management talents,technology and experience. Additionally, workers and caddies are mostly from villages and with little education, so the low-quality and running off phenomenon seriously reduced the quality of service.

\section{III)tourism The costs of golf course is high}

A standard 18-hole golf course's investment is about more than 300 million yuan, and its operation expenses are expensive. To guarantee the quality of lawns, the club generally hired foreign lawn divisions worth millions dollars. Golf course design, construction, machinery, equipment and management of the club for the most part are from abroad. The invest of a standard 18-hole are at least 12-15 million yuan a year, so the high prices restricts the development of golf.

\section{Opportunities analysis}

In recent 5 years, yunnan tourism always aims at "optimize the structure, transform and upgrade, improve quality and efficiency", and series of tourism promotional incentives are implemented. After golf"s coming into the Olympic games, the yunnan golf courses will keep moving and building the international golf tourists heavens.

\section{Threats analysis}

\section{I) common cognition bias}

When comparing golf courses built in recent years with the original construction scheme yunnan golf association scheduled, we will find the layout of parts of them are unreasonable. There are phenomenons of land violations or course building blindly. Such as the golf courses detected by the ministry of land and resources in recent half years, although few quantity, its influences and consequences are bad. If the relative sectors don't stop in time, this will cause bad consequences. So in this point the clearing up and regulation are necessary.

\section{II)the domestic competition}

Hainan golf tourism developes rapidly under the opportunity of the construction of hainan international tourism island. As in winter golf tourists can also play and its transportation is convenient, hainan golf attracts many tourists from home and abroad. Golf in Guangdong province also attracts many tourists, and most of golf tourists comes from Hong Kong, Macao and Taiwan. Meanwhile some golf clubs in jiangsu, zhejiang, tianjin, liaoning and other places begin to follow the example of Shanghai, shandong, hainan and yunnan province, actively cooperate with travel agencies and strive to expand their golf tourism business customers.

\section{III)Competition in southeast Asia}

Southeast Asia, Thailand, Malaysia, Singapore are in the tropical areas, their natural conditions are suitable for the construction of golf courses. Coupled with cheap price and the highly international openness, all of which makes these places become to the ideal places for the tourists in winter. South Korea, Japan also cause the shunt of golf tourists.

\section{THE SUGGESTIONS AND COUNTERMEASURES OF THE DEVELOPMENT OF GOLF TOURISM IN YUNNAN PROVINCE}

Golf tourism in our country is the emerging thing. There is a certain gap in the development plans compared with the western developed countries. But with the high speed development of China's economies, the government's restrictions for golf industry are bound to relax. The whole golf industry will achieve rapid development. In the process of industry competitions golf tourism in yunnan must create its own characteristics, jump from the mires of price competition and set up its own brand to make the golf tourism a leisure card in yunnan.

\section{A. Promote golf an d golf tourism common}

China's golf industry is undoubtedly a sunrise industry. Under the national policy restrictions and the high consumption threshold, the hope for the development of golf tourism is the high-speed growth of Chinese economy and the growing golf populations. So yunnan should advocates golf culture. Fundamentally, let more people to experience golf and golf tourism. Yunnan golf tour operators and golf courses can have some promotional discounts, "golf Open Day" events and other activities to encourage consumers to participate in the health, green, beneficial sports leisure activities. Let more consumers have the opportunity to go to golf course, experience golf and golf tourism. Through the effective communication and the media, the concept which golf belongs to a noble sport and high-end products will gradually be eliminated. Meanwhile, something useful should be done to arouse the consumers' interests and passions for golf and golf tourism and effectively increase the golf core population in yunnan.

B. Strengthen the golf education and train professionals of high qualities

Talents resource is the core competitiveness for the sustainable development of golf tourism. However, golf professionals' lacking in yunnan province contradicts with the rapid development of golf sports. To become the strong province, yunnan must cultivate golf tourism talents of high qualities as soon as possible according to the development of the situation. The development of golf industry in the United States are inseparable from its academic work . Only more talents of high-qualities to join, can the needs meet the golf industries' development better. Yunnan should base on and rely on the local superior resources from institutions to develop golf tourism and construct personnel training plans. It also should through various channels cultivate and train the talents as soon as possible and improve the comprehensive qualities of the existing staffs. In addition, the introduction of cultivating professional talents of golf at home and abroad to the club, which will lay the 
solid foundation for the development of golf for their advanced experiences in the management system. At the same time the development to golf youngsters should be cared for and the schools should provide students with more accesses to golf tourism opportunities, such as golf courses, golf leagues and golf tourism quality educations.

\section{Strengthen the development of golf tourism products} and improve the reception service abilities

The first is to design the characteristic courses to reflect the beautiful sceneries and ethnic customs aiming for building yunnan brands. Second, in golf tourism markets the traveling agencies plays an important role in the targets making. We should strengthen the golf tourism professional team training and set up a special market and professional operating mechanism, as well as excavating the unique tourist routes to meet the demand of special golf tourism, then we can attract more and more golf friends and improve the competitive abilities of the golf market in yunnan province.

D Intensify propaganda to build golf tourism brand in yunnan
In order to promote the popularity of golf in yunnan province, first of all, we can use sorts of advertising medias such as television, radio, newspapers and network, in order to promote golf tourism brand of yunnan characteristics. Second, varieties of the golf events activities such as business elite golf celebration parties, golf member theme parties, golf holiday campings, golf league competitions and so on should be held. Through the planning and the organizing can market be cultivated and brands be made.

\section{REFERENCES}

[1] FEIJIA.RESEARCH ON CURRENT SITUATION OF MANAGEMENT OF GOLF TOURISM MARKET IN CHINA[J]. JOURNAL OF GUANGZHOU SPORT UNIVERSITY, 2008(5)

[2] g ling, Deng yi. The suggestions and countermeasures of promoting actively the development ot golf tourism in yunnan[J]. Science and technology management in Yunnan, 2008

[3] ichao.Golf tourism research present situation probing[J]. Special zone economy,2009

[4]Zhou huating. Review of golf tourism theory research in China[J]. Journal of tianjin university of commerce, 2012(3)

[5] Li zichao. Research on Beijing Golf Tourism Cognition and Related Measures[D]. Beijing forestry university, 2009 